\title{
Activity in chicks as a function of visual loss and within-test duration
}

\section{GERALD W. MORLOCK, LAWRENCE H. FRANK, and MERLE E. MEYER Western Washington State College, Bellingham, Wash. 98225}

The activity of blinded White Leghorn chicks was compared to that of nonblinded chicks during a 12-min activity test. The hypothesis that blinded chicks would be less active than nonblinded chicks was not supported. Activity, as measured by disruption of a photobeam, increased significantly across the three successive 4-min periods of the activity test. The results suggest that the decline in activity often observed in rodents during an activity test may not always be an adequate measure of habituation to the test environment.

Browman (1942) found surgically blinded male and female rats of a 16-generation inbred line to be more active than nonblinded littermates, except under conditions of constant darkness. Blind hooded rats (Glickman, 1958), albino rats (Klein \& Brown, 1969), and C57BL/6J mice (Wimer \& Sterns, 1964) were more active than nonblinded controls. Increases in activity associated with the loss of vision have often been interpreted as 'supporting Hebb's (1955) optimal level of arousal hypothesis.

Recently, Schultz and Norberg investigated the effect of visual loss in several submammalian species: the toad (1969), the bluegill (1970a), and the lizard $(1970 \mathrm{~b})$. In each case, blinded animals were less active than nonblinded controls. Schultz and Norberg attributed the decrement in activity associated with visual loss to the lack of neocortex in the submammalian species investigated and predicted that birds deprived of vision would be less active than nonblinded controls. One purpose of the present experiment was to investigate this hypothesis.

Glickman \& Hartz (1964) investigated the activity of the guinea pig, albino rat, chinchilla, gerbil, spiny mouse, hamster, and the albino mouse in an open field. All species showed a decline in activity throughout the 10-min testing period, and further analysis indicated the "absolute" rate of this decline to be species specific. Hughes (1969) replicated Glickman and Hartz's results for the albino rat and mouse but reported that activity of the golden hamster increased across the successive 5 -min periods of the activity test. The second purpose of the present experiment was to examine the activity of an avian species throughout successive periods of an activity test.

\section{SUBJECTS}

The Ss were 76 White Leghorn cockerel chicks (Kimber) obtained from a local hatchery on the day of hatching. Within the laboratory the chicks were maintained in groups of approximately 10 in $30^{\circ} \mathrm{C}$ brooder boxes.

The experimental apparatus has been previously described in detail elsewhere (Eacker \& Meyer, 1967). Briefly, the $35 \times 25 \times 25 \mathrm{~cm}$ gray experimental chamber had an infrared photoelectric cell unit mounted to its outside surface. The photocell beam passed through a $1.3-\mathrm{cm}$ aperture, $5 \mathrm{~cm}$ above the interior hardware cloth floor. A light diffusion plate located in the center of the chamber lid allowed a light intensity of $13 \mathrm{fc}$ (Weston 614 meter) at the center of the chamber floor. The experimental chamber was housed within a sound-shielded enclosure.

\section{PROCEDURE}

The Ss were blinded by enclosing the entire head, except for the beak, in hoods fashioned from opaque black rubber balloons. Nonblinded Ss wore hoods in which "eye holes" (approximately 5-7 $\mathrm{mm}$ in diam) had been cut. Swallowing and chirping were not prevented by the hoods.

Food, but not water, was removed from the brooder boxes, and all $\mathrm{Ss}$ were hooded when approximately $18 \mathrm{~h}$ old. Half of the $\mathrm{Ss}$ in each treatment group were tested when $22 \mathrm{~h}$ old, and half were tested when $42 \mathrm{~h}$ old. Activity was defined as the number of photobeam disruptions made by a chick during a 12-min period in the experimental apparatus.

RESULTS AND DISCUSSION

A three-factor mixed analysis of variance, with successive 4 -min periods within the 12 -min activity test as the repeated measures variable (Lindquist, 1953; Type III), indicated that only the repeated measures variable had a significant effect $(\mathrm{F}=4.649$, $\mathrm{df}=2 / 136, \mathrm{p}<.05)$. The mean number of photobeam disruptions during the first period (8.18) was significantly less than during the second (12.25) and third (12.36) periods of the activity test.

The prediction that blinded chicks would be less active than nonblinded chicks was not supported by the present experiment. Although it may be postulated that the hooding technique used was not totally effective, this explanation appears unlikely because the direction of the difference between the overall means of the blind (12.92) and the not-blind (8.89) groups was opposite to that predicted by Schultz and Norberg. Perhaps the effect of sensory loss on the activity level of an organism does not depend on the presence or absence of neocortex.

The activity of the chick, like that of the golden hamster (Hughes, 1969), increased rather than decreased throughout the activity test. In the past, decreases in activity within a testing period have been interpreted as habituation to the testing environment (Glickman \& Hartz, 1964) and used as a measure of habituation (Walters \& Block, 1969). The behavior of the Leghorn chick and the golden hamster make the generality of this interpretation questionable.

\section{REFERENCES}

BROWMAN, L. G. The effect of bilateral optic enucleation on the voluntary muscular activity of the albino rat. Journal of Experimental Zoology, 1942. $91,331-344$

EACKER, J. N., \& MEYER, M. E. Behaviorally produced illumination change by the chick. Journal of Comparative \& Physiological Psychology, $1967,63,539-541$.

GLICKMAN, S. E. Effects of peripheral blindness on exploratory behavior in the hooded rat. Canadian Journal of Psychology, 1958, 12, 45-51.

GLICKMAN, S. E., \& HARTZ, K. E Exploratory behavior in several species of rodents. Journal of Comparative \& Physiological Psychology, 1964, 58. 101-104.

HEBB, $D$. $O$. Drives and the c.n.s. (conceptual nervous system). Psychological Review, 1955, 62, 243-254.

HUGHES, R. N. Exploration in three laboratory rodents. Perceptual \& Motor Skills, 1969, 28, 90.

KLEIN, D. \& BROWN, T. S. Exploratory behavior and spontaneous alternation in blind and anosmic rats. Journal of Comparative \& Physiological Psychology, $1969,68,107-10$.

LINDQUIST, E. F. Design and analysis of experiments in psychology and education. Boston: Houghton-Mifflin. 1953.

SCHULTZ, R, \& NORBERG, M. Effects of visual loss on toad, Bufos boreas, activity. Perceptual \& Motor Skills, 1969, 29, 987-990.

SCHULTZ, R., \& NORBERG, M. The effects of blindness on bluegill, Lepomis machrochirus, activity. Psychonomic Science, 1970a, 18, 180.

SCHULTZ, R.. \& NORBERG, M. The effects of visual loss on lizard. Gerrhonotus multicarinatus, activity. Psychonomic Science, 1970b, 19, 10.

WALTERS G. \& BLOCK, R. G Scopolamine effects on locomotor and exploratory activity in rats. Psychonomic Science, 1969, 17, 3-4.

WIMER, R., \& STERNS, H. Controlled visual input and exploratory activity in C57BL/6J mice. Perceptual \& Motor Skills, 1964, 18, 299-307. 